\title{
Criminal Law Policy on the Crime of Abuse to the Orang Rimba in the Bukit Duabelas National Park
}

\author{
Muhamad Erwin ${ }^{1,}$, Ahmad Zamheri ${ }^{2}$, Meiyi Darlies ${ }^{3}$, Carlos $\mathrm{RS}^{4}$, Dicky Seprianto ${ }^{2}$, \\ Irawan Rusnadi ${ }^{5}$, Alan Novi Tompunu ${ }^{3}$
}

${ }^{I}$ State Polytechnic of Sriwijaya, Palembang, Indonesia

${ }^{2}$ Mechanical Engineering Departement, State Polytechnic of Sriwijaya, Palembang, Indonesia

${ }^{3}$ Computer Departement, State Polytechnic of Sriwijaya, Palembang, Indonesia

${ }^{4}$ Electrical Engineering Departement, State Polytechnic of Sriwijaya, Palembang, Indonesia

${ }^{5}$ Chemical Engineering Departement, State Polytechnic of Sriwijaya, Palemb ang, Indonesia

"Corresponding author Email: erwin_muhamad@ymail.com

\begin{abstract}
The phenomenon of the persecution of the Orang Rimba by people from outside the Orang Rimba tribe which suggests that legal justice cannot be upheld as it should be in an environment of isolated tribal communities. This study aims to determine the legal understanding of the Orang Rimba community around the Bukit Duabelas National Park regarding criminal acts of persecution carried out by people from outside the Orang Rimba Tribe towards their members, factors that in hibit criminal law enforcement, and criminal law policies that can be adapted to provide legal protection against the Orang Rimba from persecution crimes committed by people from outside the Orang Rimba Tribe in the future. The results showed that according to the legal understanding of the Orang Rimba community if there was a conflict with an outside party accompanied by crimes of mistreatment against members of the Orang Rimba community, it was considered as a disturbance to the balance of social life. Orang Rimba considers that external social control in the form of customary fines is too easy to fulfill. Therefore, to increase the deterrent effect for people from outside the Orang Rimba tribe as the perpetrators of the persecution of their members, the Orang Rimba wants a criminal justice system that has an instrument of imprisonment to be applied as a compliment. Factors that hinder law enforcement in this crime of persecution include both juridical and non-juridical fields. The results of this study recommend that the protection of isolated tribal communities should be realized by providing special legal assistance and making advocacy programs for the Orang Rimba tribe so that disruption to them can be prevented preventively.
\end{abstract}

Keywords: criminal law policies, persecution, Orang Rimba Tribe, outsiders, Bukit Duabelas

\section{INTRODUCTION}

Law is a tool or instrument to achieve social justice. Social justice (treated fairly in social life, is one of the human rights that must be protected. Franz Magnis-Suseno in his book entitled "Power and Moral" argue that it is impossible for a human being to be respected while treating him unfairly [1]. This justice is realized by equal treatment before the law (equality before the law.) Such treatment also covers the field of criminal law. Article 2 of the KUHP which states that criminal provisions apply to all perpetrators of criminal acts. Moeljatno interprets this article, that the provisions in the KUHP apply to all criminal offenses within the territory of the Republic of Indonesia [2]. As such it includes the perpetrators of persecution against members of the Orang Rimba community by people from outside the Orang Rimba Tribe around the Bukit Duabelas National Park.

The territorial and personal principles form the basis for the implementation of criminal law against all residents throughout Indonesia, including isolated tribal communities or customary law communities. Isolated tribal communities are groups of people whose birth circumstances have limited relations with the outside world, which have properties that depend directly on nature, which have a conservative nature, which hold a deep appreciation for traditions and customs [3]. Criminal sanctions against criminal acts of persecution in Indonesia are regulated in the Criminal Law Act in Article 351, Article 352, Article 353, Article 354, Article 355, Article 356, Article 357, Article 358 of Law No. 1 of 1946 concerning the KUHP. Based on data obtained in the field on May 10, 2015 a resident of the Orang Rimba tribe near Bukit Duabelas National Park named Nugerah (43) was persecuted by a hamlet head in Sarolangun District, Junaidi (48) who was 
the Head of the Hot Water Hamlet, Subdistrict Air Hitam, Sarolangun Regency (Results of an interview with Nugerah on August 25, 2019. Nugerah was a victim of an outside crime incident [4]. On December 15, 2015, residents of the Kungkai village, Bangko District, Merangin District, Jambi Province burned 10 huts and several motorbikes owned by the local Orang Rimba tribe community (Interview with Besemen (Tengganai in the Orang Rimba Tribe group) on 20 August 2019 [5].

Then on July 3, 2019, a 23-year-old Orang Rimba resident living in the Bukit Duabelas National Park was persecuted to the point of fainting by a security unit (security guard) of the palm oil plantation company PT Jambi Agro Wiyana (Sinar Mas Plantation) for allegedly collecting palm oil. Incidentally, at that time there was a sack containing palm fruit that had been collected on the side of the road. Becontenginsistd, he was not the one who collected the palm fruits that were released from the mark. The two company security guards did not believe and persecuted him until he fainted and was left alone [6].

These cases emphasize that legal justice cannot be upheld as it should be in the environment of indigenous and tribal peoples such as the Orang Rimba in the vicinity of Bukit Duabelas National Park. This phenomenon is interesting to stuy, because there has been a form of law enforcement that has not been consistent with the application of the function of criminal law, criminal law objectives and criminal law provisions that are directly related to the customary law community.

In connection with this phenomenon, Immanuel Kant wrote that "although all members of the community agreed to dissolve the community, the last murderer who was still in prison must be sentenced to death before the resolutions the decision to dissolve the community was carried out". This must be done because everyone should receive the reward for his actions, and the feeling of revenge must not remain with members of the community, because if not so they can all be seen as people who took part in the crime which is a violation of public justice ". So according to Kant, a person must be convicted by a judge because he has committed a crime [7].

Criminal law (especially relating to the crime of persecution in the KUHP) which in theory and legislation applies to all Indonesian citizens, apparently has not been effective in resolving cases of persecution against members of the Orang Rimba tribe community around the Bukit Duabelas National Park in Jambi Province. This shows that the enforcement of criminal law greatly influences the level of criminal persecution against the Orang Rimba Tribe community. The statement can be developed through the formulation of the following problem:

1) How is the legal understanding of the Orang Rimba community towards the criminal acts of persecution carried out by people who come from outside the Bukit Dua twelve National Park area towards their members that occur around the Bukit Duabelas National Park?

2) What factors hinder the enforcement of criminal law in the crime of persecution by people from outside the Bukit Duabelas National Park area against Orang Rimba around the Bukit Duabelas National Park?
3) What alternatives can be taken as a criminal law policy to improve criminal law enforcement in providing legal protection to the Orang Rimba tribe community around the Bukit Duabelas National Park?

\section{LITERATURE REVIEW}

\subsection{Legal System and Legal Protection of Isolated Tribes}

The conceptual framework in this study uses a theoretical structure, which acts as a grund theory, namely the theory of Lawrance M. Friedman and Redcliffe Brown. According to Friedman, law is structured in a system. The subsystem consists of:

- Legal structure, namely the parts or institutions that move/function through certain mechanisms in forming, implementing, enforcing the law, or changing the law;

- The substance of the law, which can be translated as anything that is considered as law; and

- Legal Culture, which is the perception of legal subjects about a rule of law [8].

These three things are the basis for discussing legal protection for the Orang Rimba people. The Orang Rimba Tribe has their own customary law which is believed and maintained by them including the legal provisions in the process of resolving murder cases. According to Redcliffe Brown's theory, isolated tribal people hold a deep appreciation for their traditions and laws. Where in isolated tribal communities have social institutions. These social institutions are called adat fines which are the reaction of the community or most of its members to forms of behavior that are endorsed (positive sanctions) or reproach (negative sanctions) [9].

\subsection{Crime Counter Measures}

Furthermore, from the general theory, it was revealed to middle theory, which is played here by the criminal policy theory of Peter Hoefnagels. According to Peter Hoefnagels, rational efforts in combating crime can be pursued through:

- criminal law location;

- prevention without punishment; and

- influencing views of society on crime and punishment/mass media [10].

\subsection{Criminal Law Enforcement}

Furthermore, from the middle range theory, it was narrowed to the small range theory occupied by the theory of criminal law enforcement from Joseph Goldstein. He distinguishes criminal law enforcement into three, namely: First, "total enforcement", namely the scope of criminal law enforcement as formulated by total criminal procedural law is not possible, because law enforcers are strictly 
limited by criminal procedural law which includes the rules for arrest, detention, search, seizure and preliminary examination.

In addition, it might happen, that substantive criminal law itself provides limitations, for example the need for a complaint first as a condition for prosecution in offense complaint. This limited scope is called the "area of no enforcement". After the total scope of law enforcement is reduced by the area of no enforcement, a second form of criminal law enforcement appears, namely "full enforcement", in the scope where law enforcement is expected to enforce the law to the maximum. However, according to Goldstein, this expectation is considered not a realistic expectation, because of the limitations in the form of time, personnel, investigative tools, funds and so on, all of which lead to discretions and the remaining is "actual enforcement" [11].

In this study the researcher is only in the third condition namely Actual Enforcement, assuming that every crime including the criminal act of persecution against members of the Orang Rimba tribe community must:

- investigated;

- sued;

- tried / examined; and

- sentenced (if guilty).

\section{RESEARCH METHODOLOGY}

This type of research is in the form of case studies. The level of research is exploration. The sociological juridical approach. Primary data obtained from informants and secondary data obtained from the literature. The sampling technique is done by purposive sampling and data collection techniques are done through field observations, interviews, study documentation, recording with technology. The data processing technique is done by validation test through triangulation.

While the technique of analyzing data, for primary data analyzed descriptively qualitatively, while secondary data were analyzed using a content analysis approach. Then the two types of data are compared to produce a conclusion that answers the problem.

\section{DISCUSSION}

\subsection{Understanding of the Law of the Orang Rimba in the murder committed by a person of light against its members}

Understanding of the law for the Orang Rimba is as a number of regulations imposed by a power outside individual ties. It can be said that the spirit of the Orang Rimba group or its collective responsibility is the main force that guarantees adherence to adat and which makes it binding or legal. The spirit of the group, solidarity, pride for the group and the clans themselves become the cornerstone of all the rule of law in the life of the Orang Rimba community and without it, the rule of law cannot be maintained in the culture of the Orang Rimba community. The Orang Rimba are not extreme collectivities and are not reckless individualists, like humans in general they are a mixture of both. In this condition, it is seen that there is relevance between law and social institutions in which the Orang Rimba view that law is the hope of the community to be able to meet the need for peace in the life of the community.

The Orang Rimba tribe community in the vicinity of Bukit Duabelas National Park considers that what is meant by crime, the act must cause shock in the community balance sheet. This shock does not only affect the customary law in a community is violated, but also if the norms of decency, trust, and courtesy in the community are violated. Orang Rimba interpreted the traditional offense as an act that was not allowed. The root of violence that occurred against members of the Orang Rimba tribe community by people from outside the Bukit Duabelas region originated from the penetration of exploitative capitalism into the economy of the Orang Rimba tribe community and the communities or companies located around the Bukit Duabelas National Park, which makes them very dependent on the market and the acquisition of money that is only for consumptive purposes, while they remain in a position of helplessness so that they are part of a society that is exploited by people with strong economic groups.

They are pessimistic, assume there are no more rules and respect for fellow human beings. Then desperate to take or steal tools at camp pebalok. They do that because they feel the source of their lives has been stolen and spent without further ado by the 'pebalok'. For example, pebalok has cut down trees that are meaningful and valuable to them, such as sialang, centungan, tenggeris, and fruit trees, by not respecting or paying attention to the customary sanctions of the Orang Rimba in the form of fines. Until then there was a conflict between Orang Rimba and pebalok who were people from outside the Bukit Duabelas National Park area. From this description, it can be seen that law is an output of social solidarity and the result of interpretations of a sense of justice.

According to Orang Rimba understanding, if people who come from outside the Bukit Duabelas National Park area commit crimes of mistreatment to their members, then those who come from outside the Bukit Duabelas National Park area are seen as ignorant people and do not feel ashamed, because they do not understand the matter the things that have clear goodness as contained in the second law of the Parent Act with a custom verse "The road was encroached upon, the clothes were sewn and worn, sipping straw, the marketing shoulders, buried in burial, see nature stretching" it means to emulate something that has clear kindness.

The persecution itself according to the understanding of the Orang Rimba is a fact that occurs at a certain time and place, there are perpetrators, there are victims and there are weapons that are used, as stipulated in the Thesis Duabelay 
in the regulation of the Balu Valley Under the tepung tawar, luka lukih dipampas shows the meaning that people are hurting other people and cause injury due to these actions they must treat. Wounds referred to in Orang Rimba customary law consist of: low injuries, high injuries, severe injuries, and death were built (Results of an interview with Besemen, Tengganai of the Orang Rimba tribe, August 23, 2019).

The Orang Rimba hold a deep appreciation for tradition and tradition, an automatic obedience to their ties. They obey it spontaneously, without thinking, because of a mental inertia, mixed with fear of public opinion or occult punishment, or again because of the spirit of the group if not because of group instincts. On the other hand, forms of violence and killing of Orang Rimba by Orang Terang, these traits are not innate from people from outside the Bukit Duabelas National Park area, so that both substances can be reduced if socioeconomic conditions are replaced with conditions favorable to the development of selfactivity and the creative power of the Orang Rimba and people from outside the Bukit Duabelas National Park area. In addition to the current development because the Orang Rimba considers that external social control in the form of customary fines is too easy to be fulfilled by people from outside the Bukit Duabelas National Park area, then to add a deterrent effect to people who come from outside the Bukit Duabelas National Park area which as the perpetrators of the killing of its members, the Orang Rimba also wants 'hukum rajo' (state law) which has a prison legal instrument to be applied as a complement.

\subsection{Factors that hinder criminal law enforcement in crime murder by light people against Orang Rimba}

\section{- Obstacles in Community Legal Awareness Elements}

The legal awareness of the Orang Rimba Tribe is so weak. This can be known if there has been persecution of its members by outsiders, the complaint is always late reported to the police. This makes it very difficult for the police to conduct visum et repertum.

But on the other hand, the use of firearms in the form of homemade weapons or often called kecepek is growing in the village community around Bukit Duabelas National Park. Also supported by the presence of certain shops that sell our friends, namely bullets for slacking. In addition, the diminishing appreciation from outsiders of the Light for the human rights of the Orang Rimba Tribe, where the Orang Rimba are still seen as undeserving communities.

\section{- Obstacles in the Culture of the Orang Rimba}

Therefore, the culture of the Orang Rimba tribe always wants in every case of persecution the victims of which are the Orang Rimba are resolved using their customary law. Consideration of the community both the Orang Rimba and people who come from outside the Bukit Duabelas National Park area is actually more emphasized not on law enforcement, but on the values of peace and peace of the Orang Rimba community and people who come from outside the Bukit Duabelas National Park area, in addition resolution through criminal law or through the courts will not solve the problem, often only widening conflict and displeasure between Orang Rimba residents and people from outside the Bukit Duabelas National Park area.

The phenomenon of the cultural influence of the Orang Rimba in dealing with cases of persecution of its members by people from outside the Bukit Duabelas National Park area in the enforcement of criminal law is closely related to the legal system paradigm proposed by Lawrence $\mathrm{M}$. Friedman in the framework of the concept that the cultural component is the value and attitude which binds the legal system together and results in a form of law administration in the culture of society as a whole.

Based on data on criminal cases of persecution against the jungle that occurred from 2015 to 2019 and from the results of research conducted on the factors that become obstacles in law enforcement in the criminal acts of persecution against members of the tribe of the Jungle People around the twelve hills national park. , then justification can be given for the sample size.

Criminal law is the law that applies to all residents in all jurisdictions in Indonesia. That is, against all people who commit crimes in the territory of Indonesia, then the perpetrators of the law will be threatened with criminal penalties. But in reality, the legal desire and criminal law theories have not been elaborated proportionally in their application to the Orang Rimba tribe community who are victims of criminal abuse in the vicinity of Bukit Duabelas National Park. Status as an isolated tribe owned by the Orang Rimba tribe community in Bukit Duabelas National Park, Jambi Province, still influences the effectiveness of national law in resolving criminal cases of persecution that befall members of the Orang Rimba Tribe community. This shows that law enforcement affects crime against the Orang Rimba tribe community.

\subsection{Policies Used to Tackle the Crime Murder}

\subsubsection{Penal Policy}

Penalty efforts in the formulative phase need to start from a philosophical, ideological direction and on legal principles that guarantee the respect for people's basic rights to life and their cultural existence. In other words, the most important requirement before formulating plurality of customary law in legal matters is the 
preparation of a culture of respect for the basic rights (the right to life and cultural existence) of indigenous peoples/indigenous groups. Be the main study in the coming draft of the Indonesian KUHP with due regard to customary law. In this case, it does not mean that customary law that varies between one customary area and another customary area is incorporated entirely into the future KUHP, but must be taken into consideration that there are laws that live in Indonesian society whose existence is maintained.

Customary law which was previously only categorized as a folk law has been changed to a state law that applies in a particular social system, the implementation of which is still subject to existing national laws and regulations. A new state formed as a result of a long process of social change, especially a multi-ethnic society, does not automatically abolish a number of indigenous rights that existed before the state was formed. Additional penalties in the form of this customary obligation can only be imposed if the local conditions clearly require such things and if not carried out will cause serious shock in the local community.

For this reason, regulation and recognition of customary rights are no longer sufficiently stated in sectoral laws, as they have so far. At this level, what is important is not what forms of customary rights are recognized, but rather the affirmation of the recognition of these customary rights, the form of which is spelled out in lower legislation, which differs from one region and community one with the region and society that other.

If this is the case, then what is important is how the regulation of the rights of indigenous peoples themselves is carried out into laws and regulations at the level of laws. That is, there is already a need for legislation at the level of the law governing the position of customary rights in the legislation. Thus the rights of indigenous peoples cannot simply be null and voided by other laws and regulations.

Thus, the existence of violations of customary law and customary sanctions in the KUHP Nasional is very necessary because it is a fact that in some regions in our country there are still legal provisions that are not written, but still alive, obeyed and recognized as law in the regions the. The recognition of customary criminal law (customary criminal acts and customary sanctions) is to better fulfill the sense of compliance and justice that lives in certain communities. Furthermore, an alternative to the penal policy in the formative stages that can be taken to improve criminal law enforcement in providing legal protection to the Orang Rimba tribe community in Bukit Duabelas National Park is by making a penal policy in the form of laws, government regulations or regional regulations that must be pay attention to aspects related to human conditions, nature and traditions that have taken root in the culture of isolated tribal communities in Indonesia. While in the legal process in the application stage which has become an obligation for the National Police in the Bukit Dua twelve National Park and surrounding villages to enforce the law in the field by carrying out other actions according to responsible law so as to create order stability and security in the People's community Jungle and village communities around Bukit Duabelas National Park. If this is the case, then the changes that occur in all fields of one another are mutually filling and interrelated and are not contradictory and there is no conflict.

\subsubsection{Non Penal Policy}

Society in general, considers them to be primitive, a point of view that is influential to the understanding of alienated societies. Misunderstanding of understanding about isolated communities in this case, the Orang Rimba tribe, resulting in the displacement of poverty economically, socially and culturally for them. Therefore exploitative capitalism penetration into the economy of the Orang Rimba people and supported by a state system that justifies intervention with the reason to modernize or advance them through equitable development, making them highly dependent on the market and the acquisition of money that is only for consumptive purposes, while they remain in a position of helplessness, so that they are only a part of society that is exploited by people with strong economic groups.

The need for efforts to foster rational behavior and reduce /reduce acting irrational (emotional) with an understanding of the rights of others to the village community around the Bukit Duabelas National Park through the role of village officials and understanding of school children through the role of education in existing schools around the Bukit Duabelas National Park. The handling of the Orang Rimba must be carried out by multiple ministries, with great patience, and with sufficient costs rather than a modest, reliable officer, who understands well that the Orang Rimba is like a baby, not an adult human. Community participation of Orang Rimba tribes in accordance with their own wishes in the management of natural resources (forests).

In the end, alternatives that can be taken in an effort to improve criminal law enforcement in providing legal protection to the tribe of the Orang Rimba tribe, there must be integrity (integrity) between penal and non-penal efforts, where this is done to get maximum results. Penal effort that must be done is how the regulation of the rights of indigenous peoples themselves is carried out into laws and regulations at the level of the law. Thus, the rights of indigenous peoples (and of course also their obligations) cannot simply be null and voided by other laws and regulations. Non-penal efforts that need to be carried out in the legal protection of the Orang Rimba community, namely by reporting (exposing sadism) to the people of the Orang Rimba tribe extensively through mass media in the event of acts of violence against the Orang Rimba tribe community, then direct counseling to the village community around Bukit Duabelas National Park regarding criminal acts of persecution, murder, use of homemade weapons and human rights. Besides this nonpenal efforts can also be in the form of active coaching in an effort to foster rational behavior and reduce/reduce acting irrational (emotional) with an understanding of the 
rights of others to the village community around Bukit Duabelas National Park through the role of village officials and understanding of children school children through the role of education in schools around the Bukit Duabelas National Park.

Whereas on the other hand, efforts should also be made to encourage the Orang Rimba people to have a preventive, deterrent power by means of influencing and providing skills continuously in accordance with the vulnerability of crime faced by their environment. so that the disturbance to the people of the Orang Rimba tribe can be prevented.

\section{CONCLUSIONS}

Orang Rimba considers that the external social control in the form of customary fines is too easy to be fulfilled by people from outside the Bukit Duabelas National Park area, therefore to add a deterrent effect to people who come from outside the Bukit Duabelas National Park area as the perpetrators of the killings of the members of the Orang Rimba want the 'hukum rajo'(government law) which has a prison legal instrument to be applied as compliment. Efforts made by the National Police in the Bukit Duabelas National Park and surrounding areas in the occurrence of murder cases committed by people from outside the Bukit Duabelas National Park area against the Orang Rimba follow the procedures of the will of the parties to the dispute or problem. In the process of resolving the case, the police act as a mediator.

Factors that hinder criminal law enforcement in the crime of killing by people from outside the Bukit Duabelas National Park area against Orang Rimba in the Bukit Dua twelve National Park in Jambi Province, including juridical and non-juridical fields. Juridically, the criminal provisions regarding persecution in Article 351, Article 352, Article 353, Article 354, Article 355, Article 356, Article 357, Article 358 of Law No. 1 of 1946 concerning the KUHP can not be run consistently.

Non-juridical factors that hinder the enforcement of criminal law in the crime of persecution by people from outside the Bukit Duabelas National Park area against Orang Rimba in the Bukit Duabelas National Park, Jambi Province, include:

- legal awareness is still weak both in the village community around Bukit Duabelas National Park and in the Orang Rimba tribe community; and

- cultural factors of the Orang Rimba tribe, who want the cases of persecution of their members by people from outside the Bukit Duabelas National Park area to be resolved by their customary law.

While non-penal efforts that need to be carried out in legal protection of the Orang Rimba community are:

- by reporting sadism to the Orang Rimba widely through mass media in the event of acts of violence against the Orang Rimba;

- by conducting direct counseling to the villagers around Bukit Duabelas National Park regarding the ongoing crime of persecution, murder, use of homemade weapons and human rights;
- by actively developing in an effort to foster rational behavior and reduce/reduce acting irrational (emotional) with an understanding of the rights of others to the village community around the Bukit Duabelas National Park through the role of village officials and understanding of school children through the role of education in schools around the Bukit Duabelas National Park; and

- by making efforts to encourage the Orang Rimba community to have a preventive, deterrent power, namely by influencing and providing skills continuously in accordance with the vulnerability of crime faced by their environment. so that disturbance to the Orang Rimba can be prevented.

Based on these conclusions, it is suggested as follows: criminal law enforcement should be carried out consistently with handling cases that are fast, precise and honest. Then the need for technical instructions regarding the discretion for the guidelines of Polri members in accordance with other authorities that have been regulated in detail article by article in the Kitab Undang-Undang Hukum Acara Pidana. Regulations concerning the protection of isolated tribal communities contained in Article 18B paragraph (2) of the Undang Undang Dasar 1945 should be realized in lower legislation in this case the laws and government regulations for the protection of isolated tribal communities as a whole at the national level, and regional regulations Jambi Province or regency regulations around Bukit Duabelas National Park for the protection of the Orang Rimba in particular.

The Jambi Provincial Government or the regency government and related law enforcement agencies around the Bukit Duabelas National Park need to provide legal assistance specifically to the Orang Rimba tribe community

\section{ACKNOWLEDGMENT}

This research is based on work supported by State Polytechnic of Sriwijaya, Indonesia. The author thankfully acknowledges scientific discussion with our colleagues from State Polytechnic of Sriwijaya, Indonesia. The authors would like to acknowledge the anonymous reviewers at the IC FIRST 2019 for their feedback on an earlier version of the paper, and also thank to the two anonymous reviewers who provided feedback as part of this journal's review process.

\section{REFERENCES}

[1] Suseno, Franz Magnis, (2001). Kuasa dan Moral. Jakarta: PT Gramedia Pustaka Utama. pp.75.

[2] Moeljatno. (2015). Asas-asas Hukum Pidana. Jakarta: Rineka Cipta. pp. 5.

[3] Duyvendak, J. Ph. (1961). Inleiding tot de 
Ethnologie van de Indonesische Archipel (terjemahan). Yogyakarta: Jajasan Badan Penerbit Gadjah Mada. pp. 1-12.

[4] Bangun Santoso. coverage on 6.com. Allegedly Persecuted by Orang Rimba. Hamlet Head in Jambi Detained. $11 \quad$ mei 2015)https://www.liputan6.com/news/read/22301 67/diduga-aniaya-orang-rimba-kepala-dusun-dijambi-ditahan?utm_expid=.9Z4i5ypGQe GiS7w9arwTvQ.0\&utm_referrer=https\%3A\%2F $\% 2$ Fwww.google.com\%2 F).

[5] Radesman Saragih. beritasatu.com. Orang Rimba Accused of Shooting Villages. 15-12-2015) https://www.beritasatu.com/nasional/331965/oran g-rimba-dituduh-menembak-orang-desa, accessed March 12, 2019).

[6] Media Indonesia. Thursday. July 4. 2019.

[7] Muladi. (1995). Kapita Selekta Sistem Peradilan Pidana. Semarang: Badan Penerbit Universitas
Diponegoro. pp. 11.

[8] Masinambow, E.K.M. (2000). Hukum dan Kemajemukan Budaya. Jakarta: Yayasan Obor Indonesia. pp. 2.

[9] Brown, A.R.Radclife. (1968). Structure and Function in Primitive Society. London: Cohen \& West Ltd. pp. 205.

[10] Arief, Barda Nawawi. (2011). Bunga Rampa Kebijakan Hukum Pidana. Cetakan Ketiga. Bandung: Citra Aditya Bakti. pp. 29.

[11] Muladi. (1995). Kapita Selekta Sistem Peradilan Pidana. Semarang: Badan Penerbit Universitas Diponegoro. pp. 16-17. 